\title{
Birthday anniversary of Prof. D.V.M. Pavol Dubinský, D.Sc.
}

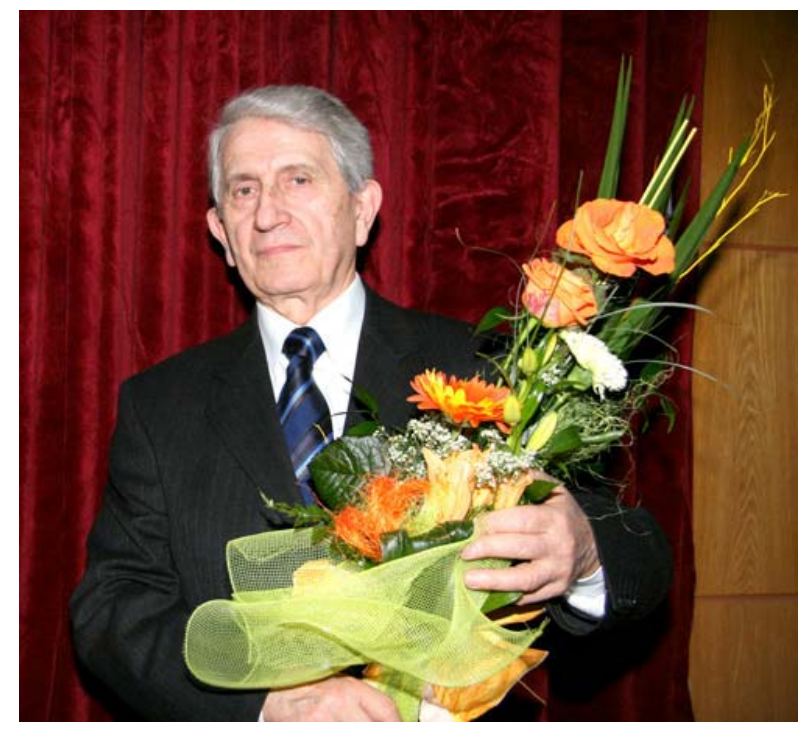

February 12, 2009 marked the $70^{\text {th }}$ birthday of a prominent Slovak parasitologist and the former director of the Parasitological Institute SAS in Košice, Prof. D.V.M. Pavol Dubinský, D.Sc.

He was born in Beniakovce, a village near Košice. Having completed his secondary education in 1956, he was admitted to the Faculty of Veterinary Medicine (formerly School of Agriculture), from which he graduated with distinction in 1962. Even during his studies he was showing profound interest in scientific work, when he acted as an assistant researcher at the Department of Chemistry and Physics. His undergraduate thesis on strongylidosis of swines was carried out at the Department of Parasitology under the leadership of Dr. Michal Breza and it preordained his future scientific route.

Since 1962 Prof. Dubinský has been based at the Parasitological (formerly Helminthological) Institute of SAS. In 1968 he joined the research team at the Department of Morphology and Physiology, then headed by an excellent supervisor and scientist Assoc. Prof. Ivan Zmoray; the team comprising also Ing. Lešt'an and Dr. Ryboš. Initially he was concerned with the effect of ultraviolet radiation on the survival of helminth propagative stages. He also pursued the studies on the physiology of developmental stages of helminths, their adaptation to parasitic mode of existence and their impact on the host organism. The scientific activity of Prof. Pavol Dubinský in recent years has been directed at research of parasitic zoonoses common to man and animals. He has achieved significant results in research on epidemiology, immunology, biology, biochemistry and molecular biology of agents causing zoonoses, particularly toxocarosis, echinococcosis, trichinellosis and toxoplasmosis. Prof. Dubinský has enjoyed a remarkable scientific career. In 1968 he defended his Candidate of Sciences thesis (C.Sc.), and in 1982 Doctoral thesis (D.Sc.). In 1991 his habilitation dissertation earned him a degree of the Associate Professor and in 2001 he was inaugurated as the Professor at the University of Veterinary Medicine in Košice.

In 1988 he was entrusted with a task to take over management of the Institute, succeeding a founder and then director, Professor Ján Hovorka. His has managed to complete five terms in office $(1988-2007)$, and he belongs to few directors with such a long lasting term of office within the SAS. With the inception of the independent Slovak Republic, the need came forward to create the basis of complex parasitological research. The scope occurred for the widely conceived parasitological studies, including the field of zoonoses and vector-borne diseases. This new orientation corresponds with the global trends and practical needs and has resulted from the need for more detailed research of newly emerging infections, related to global climatic changes. The new broader concept, designed by Prof. Dubinský and the Scientific Board led by In. Macko and later by Dr. Juriš, also led to the change in the Institute's name to the current Parasitological Institute SAS, as of April 1, 1993.

The research team of the current Department of parasitic zoonoses, still headed by Prof. Dubinský, concluded by the end of 2008 two projects of the Slovak Research and Development Agency, participated in five projects of the Scientific Grant Agency and international Norwegian project, and in the $6^{\text {th }}$ Framework programme of the Network of Excellence. The Department has become a part of the Centre of Excellence of Animal Infections and Zoonoses at the University of Veterinary Medicine within the Structural Funds of the EU, operation programme Science and Research.

In cooperation with Prof. Valent and Prof. Čatár from the Faculty of Medicine of CU in Bratislava they together have laid the foundations of the Slovak Parasitological Society and Prof. Dubinský acted as its president in 1994 - 2008, maintaining a fruitful collaboration with the Czech Parasitological Society that has resulted in organizing the Slovak and Czech Parasitological days, taking place alternatively in both countries every second year.

Prof. Dubinský has also been engaged in academic supervising in the field of parasitology, having himself led six Ph.D. students. Since 1980 he has been a member of the Czech and Slovak examining committees for defence of theses in parasitology and infectious diseases. He has also actively participated in organising Ph.D. training. With an active participation of Assoc. Prof. J. Corba, the Institute has been accredited to provide $\mathrm{Ph}$.D. training in parasitology jointly with the Faculty of Natural Sciences of CU and in the field of infectious and parasitic diseases of animals with the University of Veterinary Medicine in Košice. He makes a great effort to continually implement the results of the institute's research into the veterinary practice 
by regular lecturing at the University of Veterinary Medicine in Košice, and other universities and for a short time he acted as an invited professor at the University in Keele (Great Britain) and at the University in Zürich.

Prof. Dubinský and his team of researchers have maintained abundant international collaboration during theirs stays in Switzerland, England, the U.S.A., Austria, Denmark, Japan and in other neighbouring countries. These scientific contact and participation at numerous conferences and symposiums has contributed to him being elected into the Board of World Federation of Parasitologists and later he became its vice-president. He is also a member of the International Commission on Trichinellosis as the Slovak representative and the World Association for the Advancement of Veterinary Parasitology.

Prof. Dubinský projected himself by a rich publishing activity. He has published two monographs, the first Slovak university textbook of Veterinary Parasitology, 250 original scientific papers and presented almost 180 papers at different scientific meetings and conferences. He serves on Editorial Boards of several international and national journals and until 2008 he acted as the Chief Editor of the Helminthologia, succeeded in 2009 by Dr. Maroš Várady, D.Sc. He is also a member of the Editorial Board of Encyclopedia Beliana and Folia Veterinaria in Serbia, he served as a member of EB of Folia Parasitologica in Czech Republic, Slovak Veterinary Journal and other. Currently he is a member of several Scientific Boards, Academies, committees and the Scientific Collegium for Biological and Ecological Sciences.
In recognition of his scientific and organizational work Prof. Dubinský has received many international and national awards and distinctions. Among them the most important is the state award Pribina Cross $2^{\text {nd }}$ class for his significant contribution to social and economic growth of the Slovak Republic, awarded by the President of Slovakia Ivan Gašparovič and on the occasion of his $70^{\text {th }}$ birthday he was honoured the Golden Medal of SAS by the Scientific Board of SAS.

Professor Pavol Dubinský has rightfully earned respect not only of his fellow colleagues but also the experts in the field of the health care, veterinary medicine and agriculture. Many colleagues greatly appreciate his excellent leadership and human and friendly approach to solving various work-related and personal problems of his students, fellow workers and friends. They all join in congratulations, whishing him health, happiness and may many years to come be as happy and successful as those that have passed.

Assoc. Prof. D.V.M. Branislav Pet'ko, C.Sc Director of Parasitological Institute of SAS

The Editorial Board want to express their heartfelt appreciation to Prof. Dubinsky for all his time, effort, hard work and years of devotion to the editorial work, whishing him all the best and many more years to come. 